\title{
BENTUK DRAMATIK DAN BENTUK EPIK SEBAGAI PEMBEDA POLA PENCERITAAN TEKS DRAMA
}

\author{
Lina Meilinawati Rahayu, Aquarini Priyatna, Resa Restu Pauji \\ PASCASARJANA UNIVERSITAS PADJADJARAN \\ resa.restu@fkip-uninus.ac.id / resapalu@gmail.com
}

\begin{abstract}
Abstrak
Tulisan ini membahas dua naskah drama Matahari di Sebuah Jalan kecil (1963) dan Sandek Pemuda Pekerja (1979) karya Arifin C. Noer. Kedua naskah drama ditampilkan melalui bentuk dramatik dan epik. Naskah drama Matahari di Sebuah Jalan kecil (1963) ditampilkan dalam bentuk dramatik, sedangkan naskah drama Sandek Pemuda Pekerja (1979) ditampilkan dalam bentuk epik. Bentuk epik tersebut merupakan rumusan dari pemikiran Brecht sebagai bentuk penolakan terhadap bentuk dramatik Aristoteles. Pada naskah drama Matahari di Sebuah Jalan kecil (1963) ini, bentuk dramatik penggambaran para isu lebih diutamakan. Bentuk dramatik membawa emosi pembaca ikut hanyut dalam cerita. Sedangkan dalam naskah drama Sandek Pemuda Pekerja (1979) isu ditampilkan dalam kerangka epik. Hal tersebut dilakukan supaya pembaca menjadi kritis dan tidak ikut hanyut dalam cerita.
\end{abstract}

Kata Kunci : dramatik, dan epik.

\section{PENDAHULUAN}

Arifin C. Noer merupakan salah satu pengarang penting di Indonesia. Menurut catatan Rosidi (1991) Arifin termasuk pengarang periode 1961-an, bertepatan dengan zaman puncak pembaharuan yang dimotori Rendra, Putu Wijaya, Teguh Karya, Suyatna Anirun, dan Wisran Hadi.

Menurut Sarjono (2014) selama kiprahnya di dunia teater, Arifin C. Noer lebih mendapat pengaruh dari Bertolt Brecht, dramawan Jerman yang menjadi penggagas epic theater. Epic theater dikembangkan Bertolt Brecht sebagai perlawanan dan kritiknya yang keras terhadap teater realis dan metode berteater Aristoteles yang dikembangkan oleh Stanilavski. Metode tersebut dikenal dengan nama metode dramatik. Brecht sebagaimana dibahas Sarjono (2014) berasumsi bahwa metode Stanislavski hingga perkembangannya berusaha menjadikan teater sebagai pabrik impian. Metode berteater ini selalu membuat penonton hanyut dalam cerita yang disampaikan. Brecht justru menghendaki pemeranan tidak membuat penonton hanyut dalam ilusi tersebut. Brecht menghendaki penonton supaya tidak tergoda untuk mempercayai bahwa segala yang terjadi tersebut panggung teater merupakan representasi dalam kehidupan nyata.

Arifin memilki pengetahuan dan referensi metode berteater yang berasal dari Barat, khusunya melalui pembacaannya dari Brecth. Akan tetapi, teater Arifin bukan teater 
studi yang lahir dari bacaan saja. Melalui pengalaman dan hasil pengamatan, Arifin merupakan salah satu orang yang berhasil meletakan pijkan baru teater Indonesia. Menurut Gillit (2001) dijelaskan dalam disertasinya yang menyatakan bahwa Arifin berupaya untuk mendobrak konsep tradisional dengan menyatukan "estetika" dengan "konsep", sehingga teater yang diciptakannya lebih bergaya barat. Selain itu, Gillit juga menjelaskan bahwa Arifin melahirkan teori baru yang berdasarkan pengalaman eksplorasi dalam melakukan berbagai eksperimen untuk memunculkan teater modern Indonesia dengan segala lokalitasnya. Berdasarkan pendapat Gillit tersebut, dapat diasumsikan bahwa karya-karya Arifin, khususnya yang dikatakan Gillit dari tahun 1968-1978, lebih cenderung mengutamakan hal yang selalu dekat dengan dirinya baik yang menyangkut budaya, sosial, maupun ekonomi.

Arifin merupakan pengarang sastra drama yang selalu mengangkat permasalahan kelas bawah. Tercatat dari dua puluh sembilan naskah lakon drama yang ditulisnya, tokohtokoh cerita lebih menggambarkan sosok rakyat kecil dengan segala problematikanya. Durachman yang mengutip Anirum (1966) mengatakan bahwa karya-karya Arifin lebih memandang persoalan lingkungan bangsa dan sosok rakyat kecil yang berjuang mempertahankan hidup. Pendapat Durrachman diperkuat kembali melalui kutipan dari pernyataan Arifin dalam Pikiran Rakyat, (1985) "Saya sangat prihatin pada kedudukan buruh di Indonesia, setiap sikap kemelut perburuhan, kedudukan buruh kurang menguntungkan". Dari dua pendapat tersebut, saya berasumsi bahwa kedudukan sosok rakyat kecil selalu mendapatkan posisi yang kurang diperhatikan oleh pemerintah.

Naskah drama yang berjudul Matahari di Sebuah Jalan kecil (1963) dan Sandek Pemuda Pekerja (1979) dijadikan sebagai objek penelitian dalam tulisan ini. Penggambaran isu dalam kedua naskah tersebut dikemas dalam bentuk yang berbeda. Isu dalam naskah Matahari di Sebuah Jalan kecil digambarkan melalui pola drama yang mampu membawa emosi penonton ikut hanyut dalam cerita yang ditampilkan, sedangkan dalam naskah Sandek Pemuda Pekerja digambarkan melalui pola yang sebaliknya. Naskah drama Matahari di Sebuah Jalan kecil (1963) dan Sandek Pemuda Pekerja (1979) karya Arifin C. Noer merupakan dua naskah yang ditulis dalam waktu yang berbeda. Dua naskah ini menggambarkan isu dalam tampilan yang berbeda dilihat dari segi pola penceritaa isu-isu yang ditampilkannya.

Berdasarkan uraian latar belakang tersebut, keterkaitan antara teks-teks drama dengan isu-isu yang disampaikan dalam naskah drama Matahari di Sebuah Jalan kecil (1963) dan Sandek Pemuda Pekerja (1979) Karya Arifin C Noer akan dibahas melalui pola cerita yang berbeda dari setiap naskah. Pembahasan dalam tulisan ini difokuskan pada penggambaran bentuk dramatik dan bentuk epik dalam naskah drama Matahari di Seuah Jalan kecil (1963) dan Sandek Pemuda Pekerja (1979). Hal tersebut tentu saja menjadi dasar untuk menentukan tujuan penulisan yakni untuk mengungkap bentuk dramatik 
dan bentuk epik terkait isu buruh dalam kedua naskah drama tersebut.

\section{Landasan Teori}

Batasan mengenai drama memang telah banyak dikemukakan oleh para ahli. Berkenaan dengan hal itu, Wiyanto, (2009:3) mengemukakan bahwa drama merupakan kisah hidup manusia dalam masyarakat yang diproyeksikan ke atas panggung, disajikan dalam bentuk dialog dan gerak berdasarkan naskah, didukung tata panggung, tata lampu, tata musik, tata rias, dan tata busana. Karena drama dikaitkan dengan naskah, Rahmanto, (1988:89) berpendapat bahwa drama adalah bentuk karya sastra yang dapat merangsang gairah dan mengasyikan para pemain dan penonton sehingga sangat digemari masyarakat. Dari beberapa pendapat tersebut, saya berasumsi bahwa drama akan selalu memiliki keterkaitan antara naskah dengan pertunjukan. Berdasarkan hal tersebut, setidaknya pertunjukan drama dapat diasumsikan sebagai penuturan ulang atau penceritaan ulang dari naskah drama itu sendiri.

Selain ketiga gejala yang diaparkan tersebut, perbedaan yang paling menonjol dari teks drama dengan teks karya sastra yang lain, yakni terdapat pada strukturnya. Dalam penelitian ini, struktur drama

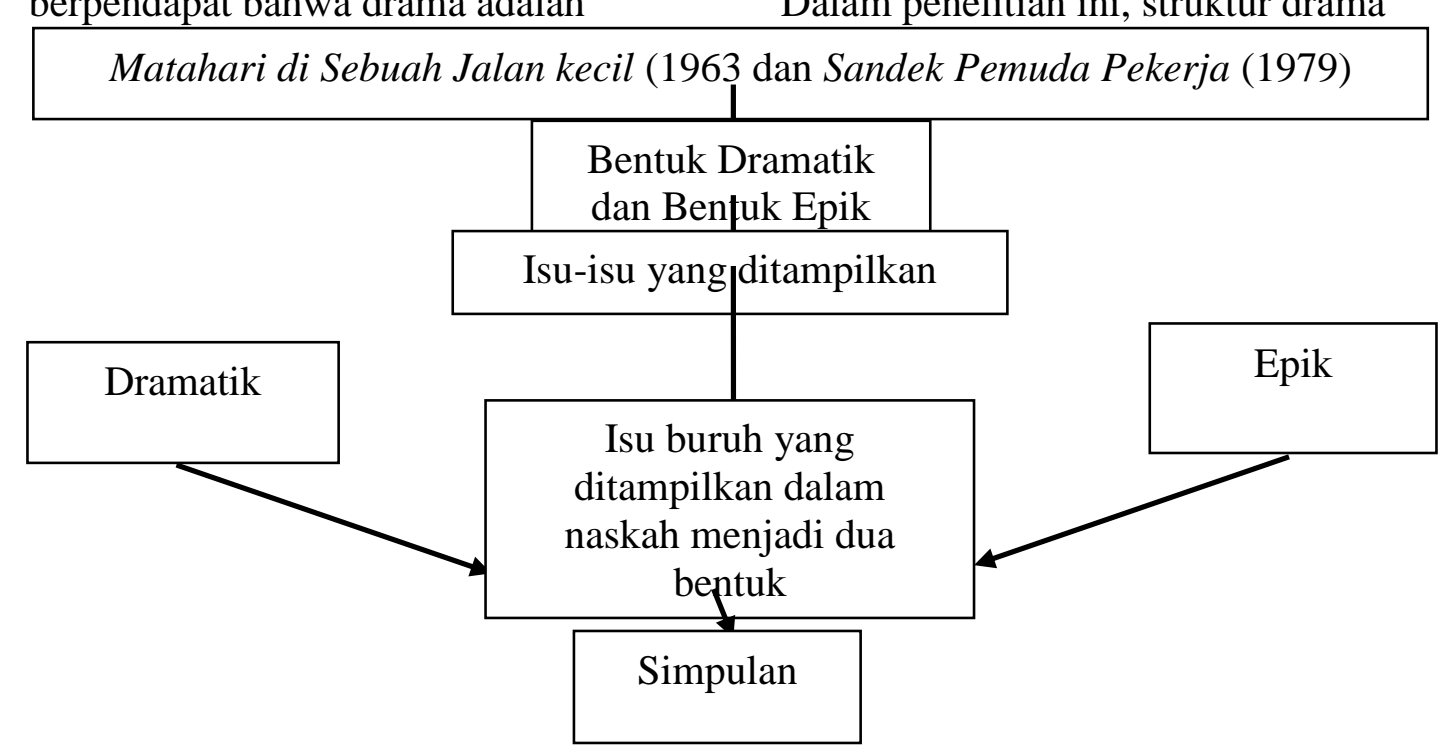

salah satu genre sastra yang hidup dalam dua dunia, yaitu sastra dan seni pertunjukan. Hal tersebut dapat diasumsikan bahwa drama memiliki keterkaitan yang erat antara teks/naskah dengan pertunjukan. Keduanya tidak dapat dipisahkan, karena naskah drama diproyeksikan untuk dipentaskan di atas panggung.

Tulisan ini akan memfokuskan perhatiannya pada naskah drama yang merupakan wujud seni bahasa tulis. Rahmanto (1988:89) mengemukakan bahwa drama adalah yang dipaparkan sebagai teori kajian yakni teori struktur drama yang dikemukakan oleh Boal yang mengutip Brecht (1985) yang mendeskripsikan sruktur drama membagi dua bentuk, yakni bentuk dramatik dan bentuk epik.

Terdapat

beberapa pengkategorian bentuk dramatik dan epik yang dikemukakan oleh Brecht. Sebagaimana yang telah dipaparkan di latar belakang, teori epik yang dibuat oleh Brecht dimaksudkan 
untuk membedakan dengan teori dramatik Aristoteles.

Struktur dramatik dan struktur epik yang telah dipaparkan tersebut, menjadi landasan teori pengkajian yang digunakan dalam tulisan ini. Akan tetapi, dari beberapa poin yang telah dikemukakan tersebut bisa saja tidak akan semua dipakai dalam penelitian ini. Hanya yang terkait secara langsung saja yang akan dipakai sebagai teori landasan pengkajian.

Analisis dialog drama dalam tulisan ini menggunakan bentuk dramatik dan bentuk epik yang dijabarkan oleh Brecht. Kedua bentuk tersebut digunakan untuk menganalisis secara struktural dua naskah drama karya Arifn C. Noer.

Bagan Alur Penelitian

Berdasarkan bagan penelitian tersebut, alur penelitian yang dilakukan dalam tulisan ini dimulai dengan menganalisis Matahari di Sebuah Jalan kecil (1963 dan Sandek Pemuda Pekerja (1979) melalui bentuk dramatik dan epik. Melalui analisis terhadap kedua karya tersebut diperoleh data bentukbentuk dramatik dan epik. Data yang dimunculkan dalam tahap ini adalah data yang terkait dengan isu-isu yang terkait dengan sosok rakyat kecil. Melalui analisis ini diperoleh yakni terdapat perbedaan penggambaran isu yang ditampilkan dalam naskah berdasarkan hasil analisis bentuk dramatik dan epik

\section{PEMBAHASAN}

Berkaitan dengan analisis struktur yang dilakukan pada bab ini, dua naskah drama yang dianalisis, yakni Matahari di Sebuah Jalan kecil (1963) selanjutnya disingkat MATAHARI dan Sandek Pemuda Pekerja (1979) selanjutnya disingkat
SANDEK. Struktur dramatik dan struktur epik yang membentuk isu buruh dideskripsikan lewat perbedaan dramatik dan epik dalam kedua karya drama Arifin C. Noer. Penggambaran dramatik terdapat dalam struktuk drama MATAHARI. Sedangkan penggambaran epik terdapat dalam struktur drama SANDEK. Struktur dramatik terdiri dari; Pertama, setiap pemikiran tokoh membentuk karakter penokohan masing-masing (pikiran yang membentuk karakter tokoh yang baik, dan jahat), dengan kata lain karakter tokohlah yang menjadi subjek dari pembaca atau penonton. Kedua, Manusia adalah suatu anugerah, baku, tidak dapat diubah, dan tetap ada, sehingga sering dijadikan sebagai tokoh dalam teks drama. Ketiga, Konflik yang digambarkan merupakan bentuk tindakan dramatis yang mengalir lurus dan berkaitan: struktur karya sastra adalah skema kehendak dalam konflik. Keempat, Dramatik menciptakan empati dari emosi pembaca/ penonton sehingga pembaca/penonton mengganggap bukan sebuah akting. Kelima, Pada akhir cerita, cerita tersebut mampu meluapkan (menjernihkan) semua perasaan pembaca. Keenam, Pada akhir cerita, selalu tercipta sebuah "amanat" baru. Dan ketujuh, dasar dramatik berasal dari pengalaman yang mampu membangkitkan perasaan sedih, gembira, dan lainlain.

Argumen tentang struktur dramatik yang telah dipaparkan, dihubungkan pula dengan struktur epik yang merupakan kebalikan dari struktur dramatik. Pertama, masyarakat yang membentuk pikiran para tokoh. Pada kondisi ini, karakter tokoh menjadi objek dari pembaca 


\begin{tabular}{|c|c|c|c|}
\hline No & $\begin{array}{ll}\text { Analisis } & \text { Bentuk } \\
\text { Dramatik } & \end{array}$ & Analisis Bentuk Epik & $\begin{array}{l}\text { Keterkaitan } \\
\text { dengan Stuktur } \\
\text { Drama }\end{array}$ \\
\hline 1. & \begin{tabular}{l}
\multicolumn{2}{l}{ Penggambaran tokoh para } \\
buruh membentuk \\
karakter penokohan \\
masing-masing.
\end{tabular} & $\begin{array}{l}\text { Penggambaran para tokoh buruh } \\
\text { dan tokoh pemilik pabrik susah } \\
\text { untuk diidetifikasi karakter } \\
\text { penokohannya. }\end{array}$ & $\begin{array}{ll}\text { Tokoh dan } \\
\text { Penokohan }\end{array}$ \\
\hline 2. & $\begin{array}{l}\text { Tokoh buruh sebagai } \\
\text { subjek bagi pembaca }\end{array}$ & $\begin{array}{l}\text { Para tokoh buruh menjadi objek } \\
\text { dari pembaca }\end{array}$ & Tokoh \\
\hline 3. & $\begin{array}{l}\text { Para tokoh yang } \\
\text { digambarkan adalah } \\
\text { manusia seutuhnya. }\end{array}$ & $\begin{array}{l}\text { Para tokoh yang digambarkan } \\
\text { bervariatif dan berubah-ubah. }\end{array}$ & Tokoh \\
\hline 4. & $\begin{array}{l}\text { Skema alur yang progresif } \\
\text { menciptakan suasana } \\
\text { dramatis sehingga mampu } \\
\text { menimbulkan empati dan } \\
\text { simpati mengenai } \\
\text { kehidupan buruh }\end{array}$ & $\begin{array}{llr}\text { Skema alur yang dibuat acak } \\
\text { membuat pembaca } & \text { yang } \\
\text { membuatnya bertindak sebagai } \\
\text { pengamat dan kritis. }\end{array}$ & Alur \\
\hline 5. & $\begin{array}{l}\text { Konsep realis isu } \\
\text { perburuhan yang diangkat } \\
\text { dalam cerita didasarkan } \\
\text { pada kontradiksi ekonomi } \\
\text { dan sosial melalui } \\
\text { perspektif buruh. }\end{array}$ & $\begin{array}{l}\text { Isu perburuhan yang diangkat } \\
\text { didasarkan pada kontradiksi } \\
\text { ekonomi, sosial, dan politik, (para } \\
\text { buruh dan pemilik pabrik) yang } \\
\text { mungkin bisa dikatakan sebagai } \\
\text { bagian dari aktualisasi sejarah. }\end{array}$ & Tema \\
\hline
\end{tabular}

digantikan/diubah. Ketiga, Tindakan

dramatik dibentuk melalui

Kontradiksi ekonomi, sosial, atau politik. Hal tersebutlah yang menjadi dasar dari karya. Keempat, aktualitas sejarah orang dan peristiwa menjadi bagian dari sejarah sebagai lawan menjadi sejarah mitos, legenda, atau fiksi atau tindakan dramatis, sehingga mampu mengubah pembaca/penonton menjadi pengamat dan mengumumkan kesadaran kritis. Pada kegiatan ini pembaca/penonton memiliki kapasitas untuk melakukan tindakan. Kelima, pengetahuan yang diperoleh mengungkapkan kesalahan masyarakat. Beberapa perbedaan yang ditunjukkan oleh Brecht merujuk lebih dari perbedaan epik, dramatis, dan bentuk liris dalam karya sastra. Akan tetapi, dalam penelitian ini epik dan dramatiklah yang digunakan/ dihubungkan untuk
Berdasarkan analisis yang telah dilakukan, struktur dramatik dan struktur epik dalam naskah drama Matahari di Sebuah Jalan Kecil (1963) dan Sandek Pemuda Pekerja (1979) membentuk perbedaan pola penggambaran isu buruh.

\section{Hasil Analisis Bentuk Dramatik dan Bentuk Epik dalam Matahari Di Sebuah Jalan Kecil (1963) dan Sandek Pemuda Pekerja (1979)}

Berdasaran tabel di atas, perbedaan bentuk dramatik dengan bentuk epik menggambarkan secara jelas perbedaan antara naskah Matahari di Sebuah Jalan Kecil dan naskah Sandek Pemuda Pekerja. Naskah Matahari di Sebuah Jalan Kecil dibentuk secara dramatik melalui;

(1) penggambaran tokoh melalui dialog yang disampaikan para 
buruh (Si Kacamata, Si Kurus, Si pendek, Penjaga Malam, Si Peci, dan Si Tua) membentuk karakter penokohan masingmasing,

(2) para tokoh bertindak sebagai subjek (penyampai pesan/informasi) bagi pembaca,

(3) para tokoh yang digambarkan adalah manusia seutuhnya,

(4) skema alur yang progresif menciptakan suasana dramatis sehingga mampu menimbulkan empati mengenai kehidupan buruh, dan

(5) Konsep realis isu perburuhan yang diangkat dalam cerita didasarkan pada kontradiksi ekonomi dan sosial melalui perspektif buruh.

Sedangkan dalam naskah Sandek Pemuda Pekerja dibentuk secara epik melalui;

(1) karakter penokohan para tokoh buruh (khususnya Sandek, dan Darka) dan tokoh pemilik pabrik (Kepkam, Tuan, Yang Satu, Manajer, dan Pemilik) susah untuk diidetifikasi, karena peran mereka selalu berubah dan juga peran serta dari dialog tokoh yang lain terkadang membuat bingung,

(2) para tokoh buruh menjadi objek dari pembaca,

(3) para tokoh yang digambarkan bervariatif dan berubah-ubah,

(4) skema alur yang melompatlompat seperti jejaring laba-laba membuat pembaca harus berpikir keras untuk memahami isu-isu yang angkat dalam cerita, dan

(5) isu perburuhan yang diangkat didasarkan pada kontradiksi ekonomi, sosial, dan politik, (para buruh dan pemilik pabrik) yang mungkin bisa dikatakan sebagai bagian dari aktualisasi sejarah. Berdasarkan penjelasan mengenai bentuk dramatik dan epik, dapat diasumsikan bahwa melalui bentuk dramatik, naskah Matahari di Sebuah Jalan Kecil mampu membawa emosi pembaca ikut dalam suasana dramatis cerita, sedangkan melalui bentuk epik naskah Sandek Pemuda Pekerja malah membuat pembaca mejadi pengamat, sadar, dan kritis.

\section{SIMPULAN}

Naskah drama yang berjudul Matahari di Sebuah Jalan kecil (1963) dan Sandek Pemuda Pekerja (1979) mengangkat isu buruh terkait denga kelas dan kepentingan kelas. Dalam kedua naskah tersebut ditampilkan dalam bentuk yang berbeda. Isu buruh dalam naskah Matahari di Sebuah Jalan kecil ditampilkan melalui pola dramatik, sedangkan dalam naskah Sandek Pemuda Pekerja ditampilkan melalui pola epik. Dari dua bentuk pola yang berbeda tersebut menggambarkan buruh dari sisi yang berbeda.

Ditinjau dari bentuk dramatik dan epik terhadap penggambaran isu buruh dalam dua teks drama Matahari di Sebuah Jalan kecil (1963) dan Sandek Pemuda Pekerja (1979), baik secara struktur maupun secara substansif memiliki perbedaan. Melalui bentuk dramatik dalam teks drama Matahari di Sebuah Jalan kecil (1963) membuat pembaca hanyut dalam cerita dan terlibat langsung secara emosional. Secara dramatik drama ini menunjukan isu kelas sebagai penjelasan relasional kesempatan kehidupan ekonomi kelas atas dan kelas bawah. Pembaca dibawa ke dalam persfektif para buruh, 
sehingga keberpihakan para pembaca atau penonton akan lebih besar. Sedangkan bentuk epik dalam teks Sandek Pemuda Pekerja (1979), membuat pembaca menjadi pengamat dan tidak ikut hanyut dalam cerita. Hal tersebut terjadi karena isu yang terkait dengan buruh digambarkan dalam dua persfektif, yakni persfektif buruh dan pemilik pabrik. Hal tersebut mengakibatkan penonton akan bertidak objektif dan berfikir secara rasional dalam memahai isu yang digambarkan.

\section{DAFTAR PUSTAKA}

\section{Sumber dari Buku:}

Aminuddin. 1987. Pengantar Apresiasi Karya Sastra. Bandung: Sinar Baru

Durachman. Yoyo C. 1996. Enam Teater: Mengenal Tokohtokoh Teater Modern Indonesia. Bandung. STSI Press.

Gillit. Fred C. 2001. produksi teatrikal ditulis dan diarahkan oleh Rendra, Arifin C Noer, and Putu Wijaya antara 1968-1978

Hasanuddin, WS. 2009. Drama Karya dalam Dua Dimensi. Bandung: Angkasa

Jabrohim. 1996. Teori Penelitian Sastra. Yogyakarta. Pustaka Pelajar

Laurenson, Diana and Alan Swingewood. 1972. Sociology of Literature. London:

Paladin
Luxemburg, Jan Van dkk. 1989. Pengantar Ilmu Sastra (Terjemahan Dick Hartoko). Jakarta: Gramedia

Magnis-Suseno, Franz. 2005. Pemikiran Karl Marx: Dari Sosialisme Utopis ke

Perselisihan Revisionisme. Jakarta: PT Gramedia Pustaka Utama

Marx, Karl.1892. The Poverty of Philosophy. Moscow. Foreign Languages Publishing House.

Noer. Arifin Chairin. 1963. Matahari di Sebuah Jalan kecil (naskah ketik ulang). Bandung. STSI

Kumpulan Drama Satu. Jakarta: Media press

1979.

kumpulan naskah drama Orkes Madun. Pustaka Firdaus bekerjasama dengan Yayasan Adikarya IKAPI dan The Ford Foundation .1979. Sandek Pemuda Pekerja. (naskah ketik ulang). Bandung. STSI

Putri. Asny Eka. 2014. Perjuangan Kelas Proletar Dalam Novel Kani Kousen Karya Kobayashi Takiji Melalui Pendekatan Teori Marxisme". Program Studi S1 Sastra Jepang Jurusan Bahasa dan Sastra Fakultas Ilmu Budaya Universitas Brawijaya

Rahayu, Lina Meilinawati. 2011. Disertasi: Transformasi dalam Pementasan Naskah Drama Saduran: Studiklub Teater Bandung (STB). Yogyakarta: Universitas Gadjah Mada 
Rahmanto, B. 1996. Metode Pengajaran

Sastra. Yogyakarta: Kanisius

Ratna, Nyoman Kutha. 2008. Teori, Metode, dan Teknik Penelitian Sastra.

Yogyakarta: Pustaka Pelajar

Radjab, Suryadi A. 2001. Ekonomi Politik Buruh. Bandung. Labour Education Center

Rosidi, Ajip. 1991. Ikhtisar Sejarah Sastra Indonesia. Bandung. Binacipta

Saini, KM. 1985. Dramawan dan Karyanya.

Bandung: Angkasa.

Sarjono, Agus R. 2014. 33 Tokoh Sastra Indonesia Paling Berpengaruh. Jakarta. Gramedia

Satoto. Sudiro. 2011.Tokoh dan Penokohan dalam Caturlogi Drama Orkes Madura Karya Arifin $\quad C$. Noer. Kemendikbud.

Selden, Raman. 1993. Panduan Pembaca Teori Sastra Masa Kini. Yogyakarta. Gadjah Mada University Pess.

Semi, Antar. 1982. Kritik Sastra. Bandung: Angkasa. 1990.

Metode Penelitian Sastra. Bandung: Angkasa.

Teeuw, A. 1982. Sastra dan Ilmu Sastra. Jakarta: Pustaka Jaya

Tyson, Lois. 2006. Critical Theory Today: A User-Friendly Guide. New York:

Routledge Taylor \& Francis Group
Wibowo, Suluh Edhi. 2010. Pertentangan Antarkelas dalam Novel Germinal Karya Émile Zola. semarang. Magister ilmu susastra universitas diponegoro

\section{Sumber dari Internet:}

Aidit, D.N. 1963. Dekon Dalam Ujian. Yayasan "Pembaruan", Jakarta. Diedit dan dimuat oleh Ted Sprague (18 November, 2012) https://www.marxists.org/ind onesia/indones/1963AiditBuruhDekon.htm

Ahmad, Ali. Minggu, 12 Mei 2013 | 14:12. Beda Perbudakan Buruh Orba dan Sekarang. http://www.tempo.co/read/ne $\mathrm{ws} / 2013 / 05 / 12 / 064479741 / \mathrm{B}$ eda-Perbudakan-Buruh-Orbadan-Sekarang

Aisyah, Nenden Lilis.

Error! Hyperlink reference not valid.

Rekson Silaban. Kamis, 4 Desember 2014. Pergerakan Buruh Indonesia.

http://nasional.kompas.com/r ead/2014/05/01/1217264/Per gerakan.Buruh.Indonesia

Sudiro Satoto. http://badanbahasa.kemdikbu d.go.id/lamanbahasa/produk/ $\underline{51}$ 